\title{
Targeting, Rhetoric and the Failure of Grassroots Jihad
}

\author{
by Gilbert Ramsay
}

In this paper I examine the apparent failure of Al Qaeda ideologues, not for want of trying, to incite a widespread campaign of 'individual jihad'. Not only are instances of genuinely 'leaderless' jihadist violence rare, they also tend to be more discriminate and less lethal in their targeting than the operations which Al Qaeda expresses a discursive preference for, and which it attempts to carry out. I argue that an explanation for the rather constrained nature of grassroots jihadist violence can be found, rather paradoxically, in the logic of collective action, which seems to underlie the rhetorical attempts of jihadist ideologues to incite violence. I then briefly examine the possible implications of this for understanding what makes for a successful 'leaderless' terrorist campaign.

\footnotetext{
J
} ihadist terrorism is supposed to be the pre-eminent threat to the security of Western countries. But it is a threat that, despite the very real and terrible suffering and loss experienced by the victims of those attacks which have taken place, is looking increasingly hollow. To some extent, of course, the prospect of an unstoppable wave of carnage by Islamist radicals has been a self-denying prophecy, since it has led governments to allocate enormous resources to preventing it. Even so, this is not quite explanation enough. Because a major part of the discourse about the Al Qaeda threat has been premised on the idea that Al Qaeda - like Arnold Schwarzenegger's mercurial antagonist in Terminator 2 - was such a supple and sophisticated opponent that it would render old-fashioned counter-terrorism techniques useless. Having 'mutated into an ideology, a 'youth movement',[1] a 'brand',[2] a 'meme',[3] a 'way of working',[4] it was no longer possible to stop Al Qaeda just by wiretapping and arresting people. Because as long as the group's ideology retained its appeal, terrorists would continue to spontaneously generate, bursting out violently where they were least expected.

If grass roots jihad actually did work this way, it would indeed be difficult to stop. While the idea that anyone can make an effective bomb simply by following instructions downloaded from the Internet now looks increasingly implausible, there are still plenty of readily imaginable ways in which a person, were he solely motivated by the aim of achieving terror and devastation. As the Al Qaeda ideologue Adam Gadahn has observed, there are many American states in which firearms are freely available.[5] A person prepared to fire even a handgun at close range into the crowd in a shopping mall could cause significant amounts of death and injury and certainly widespread terror. For those to whom firearms are not so readily available, the material culture of modern life would still seem to afford plenty of lethal options. There are, for example, plenty of ways to kill with a car or a larger vehicle and, without being too specific, there are various other types of machinery freely available which could quite readily be used to lethal effect.

In reality, jihadist terrorism as it has actually occurred in Western countries has been a much more limited phenomenon than apocalyptic pronouncements suggested it would be. It has been limited in two senses. Most obviously, the number of actually attempted attacks has been limited - and the number of attacks which were in any sense successful more limited still. By a generous definition of success, there have to date been twelve successful jihadist attacks on Western soil since 9/11, of which only four killed more than two people, and a further four of which killed no one at all. 


\section{Journal of Terrorism Research}

That jihadist terrorism has not been more successful is good news, of course. But it does raise a troublesome difficulty. With so relatively much engagement in so-called 'violent extremism' occurring compared to the very limited amount of actual violent action, anticipating the terrorist attacks that will occasionally occur becomes a bit like looking for a needle in a haystack. This is made more problematic, moreover, by the fact that the potential range of acceptable targets and attack methods is so apparently vast. While guns and bombs remain the weapons of choice, jihadist discourse envisages the use of everything from nuclear weapons to rocks, from crippling the infidel's economy with cyberattacks to running him over with your SUV. As for targets, the only limits which seem to be regularly articulated are prohibitions on the deliberate targeting of children, women, religious leaders[6] and other Muslims. And, as the gun massacres that recently occurred in Toulouse remind us, that these limits are sometimes articulated offers no guarantee that they will actually be abided by.

And yet, if we look carefully at the targeting discourses that are articulated by Al Qaeda, and by would be entrepreneurs of global jihad more broadly, there are, nonetheless, some apparent tensions and inconsistencies to be observed between the sorts of violence which jihadists seem to be calling for, and the sorts of violence which Western jihadists actually undertake.

This disjuncture is not immediately obvious. As I have just noted, global jihadist discourses envisage a very wide range of possible attack scenarios, and this heterogeneity is ostensibly mirrored in real life (probably as much because of post-hoc approval of attack methods that have actually been used as the other way around). Real life jihadist attacks in the West have been actually been attempted by means as diverse as truck, arson, poison, knife and sabotage against targets ranging from nightclubs to politicians.

Where the tension seems to lie is in the level of discrimination in the attacks. Al Qaeda's communiqués do not constitute a single, fully coherent message with regard to targeting priorities. And this coherence unsurprisingly decreases if we extend our focus from the messages of Al Qaeda 'central' to other global jihadist ideologues such as Abu Mus'ab al-Suri. Nonetheless, it seems clear that the type of attacks Al Qaeda most wants to see are not directed attacks against particular, selected groups of people, but rather mass casualty attacks against Western civilians in general. The reason for this is not that $\mathrm{Al}$ Qaeda wishes it to be thought that it harbours any particular hatred for these people. On the contrary, Usama bin Ladin repeatedly observed that he did not harbour personal enmity towards the American people, and even (albeit for propagandistic purposes) expressed his sympathy for the families of 9/11 victims.[7] Rather, it is that Al Qaeda typically tries to present its jihad in strategic terms, not as a good in its own right, but rather as a contingent necessity - a means to an end which will stop once that end is achieved. Al Qaeda's violence is classic terrorism in the sense defined by Alex Schmid in that the targets of its violence are not the real targets which are, rather, the governments of the citizens targeted.[8]

Perhaps the best evidence of this is not to be found in Al Qaeda's bold announcements of terrible blows which it will strike any minute now against the hearts of the crusader nations, but rather in the way in which Al Qaeda communiqués seem to address the subject of much more limited and less ambitious methods of attack as, for instance, where Ayman al-Zawahiri points out in Knights Under the Prophet's Banner:

Tracking down the Americans and the Jews is not impossible. Killing them with a single bullet, a stab of a device made up of a popular mix of explosives, or hitting them with an iron rod is not impossible. Burning down their property with Molotov cocktails is not 


\section{Journal of Terrorism Research}

difficult. With the available means, small groups could prove to be a frightening horror for

the Americans and the Jews.[9]

The methods which Al-Zawahiri is speaking of here, writing in 2002, are realistically simple. However, the basic purpose of the campaign he envisages is the same as that the much more ambitious martyrdom bombings which Al Qaeda leaders have called for on other occasions such as, for example, Bin Ladin's speech responding to the invasion of Iraq. It is an indiscriminate campaign of killing and destruction aimed at causing 'a frightening horror for the Americans and the Jews'.

[10]

Al Zawahiri's exhortation anticipates the rather more detailed recommendations of Abu Mus'ab alSuri, who, in The Global Islamic Resistance Call, calls for attacks on a wide range of specific Western targets, including political leaders, industrial centers, military bases, information networks, the media, tourist hotspots, and so on.[11] However, despite the range of targets, Al-Suri is, again, quite clear about the basic point of carrying out attacks, which he sees as straightforwardly coercive in aim. With the exception of Jews, whom Al-Suri apparently sees as intrinsically deserving of being targeted anywhere other than in synagogues, there purpose of attacks is, again, not to punish particular individuals, but rather to exert pressure on governments to withdraw their forces from Muslim lands.

Interestingly, during his time with Al Qaeda in the Arabian Peninsula, Anwar al-'Awlaqi seems to have influenced a slightly - though not entirely - different set of targeting priorities. The air freight bomb package plot of which Al-'Awlaqi was an important part looks like an attempt to please multiple competing interests in terms of targeting priority. It was aimed simultaneously at the American economy, at president Obama via an attack on his home city, and at two synagogues, one of which was a conservative congregation with the word 'Zion' in its name, and the other specialized in serving for gay and lesbian Jews.[12] Al 'Awlaqi also gave much more attention to cultural issues than other major Al Qaeda ideologues have characteristically done. While Bin Ladin and al-Zawahiri did issue threats against Denmark in response to the so-called 'cartoons controversy', they did not address the subject at any great length. Moreover, up to this point, blasphemy against Islam did not figure as a theme of any significance in Al Qaeda targeting discourse, despite the fact that, since the Rushdie Affair, which remained in the headlines through the 1990s, they could not have been unaware of it as an issue. Finally, the violent response they advocated remained essentially strategic in character - the indiscriminate targeting of Denmark as a whole. By contrast Al-'Awlaqi and his associates not only devoted a great deal of attention to the issue through speeches such as 'The Dust will Never Settle Down' and a special section of Inspire magazine,[13] they also made a point of emphasising the targeting of cartoonists as individuals. This is of course not to say that Al-"Awlaqi did not also call for indiscriminate attacks on civilians quite the contrary. But the possibility of more expressive forms of violent action as an addition to the targeting repertoire of the 'global jihad' seems to have a higher priority in his work.

By contrast, truly indiscriminate attacks on ordinary civilians are a surprisingly limited part of the overall set of attacks attempted by jihadist terrorists in the West. Moreover, where there have been serious attempts (successful or otherwise) at such attacks, it has usually turned out that relatively formal organisations based in the so-called 'lands of jihad' have played are fairly significant role in making them happen. This has turned out to be the with regard to the Madrid and London bombings, as well as, for example, the transatlantic liquid bomb plot and the Times Square attempted bombing. Genuine, credible, self-starter attempts at mass casualty bombings by jihadists 


\section{Journal of Terrorism Research}

in the West are, to say the least, few and far between, although the $21 / 7$ attacks would seem to be an example.[14]

Indeed, jihadist attacks in the West appear to clump broadly into two types. The first are actual or attempted mass casualty bombings, often but by no means always intended as suicide operations and directed at ordinary civilians and public infrastructures. These operations, as just stated, almost always involve training and perhaps even command and control from abroad. The second type of operation is typically carried out using firearms, and is usually directed against targets which are in some sense discriminately selected, most commonly soldiers. These attacks tend not to involve foreign travel, training or direction, and the target may be quite opportunistically selected.

It is worth observing at this point that attacking soldiers based in their home countries (which would account for all but one of the incidents in which soldiers have been attacked by jihadists in the West), while it might appear to be in keeping with the strategic framing which Al Qaeda tends to give its calls for individual jihad, is arguably not an optimal choice from Al Qaeda's point of view. Attacking soldiers, while it may provoke outrage, is not likely to provoke widespread fear in a civilian population. Moreover, where soldiers are already committed to a conflict and are therefore risking their lives as a matter of course on the battlefield, it is highly unlikely that the death of a few of them at home will exert pressure on political leaders to bring them back.

Indeed, a careful examination of what jihadist targeting discourses have to say about attacks on soldiers and army bases in Western countries would seem to reinforce this. Al Suri, for instance, in calling for attacks on army bases, specifies particularly that these would ideally be directed against American troops stationed abroad (presumably in the hope that such attacks would be more likely to actually prompt a withdrawal).[15] Similarly, in praising the actions of Fort Hood shooter Nidal Malik Hassan, Adam Gadahn asks (perhaps a little ruefully) why similar actions are not being undertaken against American army bases in Arabic countries.[16] Naturally, Al Qaeda's leaders are not likely to turn up their noses at a domestic attack on US soldiers which falls into their laps, but there seems little reason to think that such attacks are a matter of particular priority for them to the extent that they are able to choose.

How can we make sense of all this? Decentralised, networked, even leaderless terrorism can be understood as a particularly extreme form of collective action dilemma. On the one hand, the individual is being asked to carry out a particularly risky and costly form of action. On the other, the ability of the organisation to compensate or exert pressure on him or her is virtually nil. It therefore lies at the very edge of what models of human behaviour can explain. The theorist must either accept a version of rationality bounded by a set of boundaries so bespoke as to seem almost arbitrary or, alternatively, to abandon any attempt at understanding the actions attempted as rational and look to some other model instead.

Amongst attempts to understand terrorist actions through a rational choice framework at the individual level, we find the 'integrated framework' proposed by Dipak K. Gupta,[17] who in calling for an extension of rational actor theory to encompass 'the need to belong' essentially seems to be reinventing certain versions of the notion of bounded rationality.[18] In doing so, Gupta not only sacrifices the precision of neoclassical views of rational action, but also fails to provide anything more than a rather vague appeal to intra-group dynamics to replace it. Gupta's work references and otherwise recalls that of Sageman, but Sageman, who commits himself to 'middle range analysis' simply refuses to engage seriously with the level of the individual.[19] Sageman's 'bunch of guys' often seems to be a black box out of which radical behaviour simply emerges, without even a clear sense of the ingredients that went into it, let alone the mechanisms that forged them into terrorist action. 


\section{Journal of Terrorism Research}

A more intellectually satisfying approach is to be found in the work of Eli Berman, [20] who, following micro-economically focused rational choice theorists of religion like Bainbridge and Stark [21] and particularly Laurence Iannacone,[22] argues that religious terrorism and behaviours like suicide bombing are to be understood as by products of organisations which have evolved to deal effectively with the 'free rider' problem in an environment otherwise highly conducive to corruption and defection. These organisations demand that people conform to a particularly stringent set of ideological conditions in order to weed out those who are not seriously committed. This makes them better able to provide for those who are within the charmed circle, which in turn provides an incentive for a rational, self-regarding actor to conform. But while Berman's work is interesting with regard to groups such as the Taliban or Hamas, he is, as he admits, at a loss to explain how a much looser entity like Al Qaeda functions, except to suggest that it parasitically recruits from previously radicalized and committed individuals.

This line of argument would bring us, with regard to Western contexts, to the work along the lines of that performed by Quintan Wiktorowicz on the movement Al Muhajiroun in the UK.[23] A1 Muhajiroun were not explicitly committed to carrying out acts of terrorism and in Wiktorowicz's judgement this commitment was genuine. However, the movement did help to overcome some of the obstacles to jihadist mobilization by separating people from the support networks and social capital offered by mainstream society, systematically indoctrinating them with an ideological outlook closely related to Al Qaeda's, creating a close-knit group of like minded activists, and getting them used to engaging in regular, somewhat risky, political activities together.

Wiktorowicz's analysis of Al-Muhajiroun presents the group as not dissimilar from a New Religious Movement in the way it started by exploiting 'cognitive openings' in potential recruits, before getting them involved in a set of behavioural processes aimed at causing them to gradually sink more and more costs into the movement, on the one hand by encouraging them to devote very large amounts of time and effort to the group's study sessions while, as a corollary, sacrificing ordinary work and leisure opportunities.

The problem with Wiktorowicz's work for understanding leaderless jihad is mainly that it is an account of how people joined Al-Muhajiroun, not an account of how people come to be involved in 'jihadism' per se. Indeed, he points out that while Muhajiroun were operating in the UK, they acknowledged the 'jihadist' to represent a rival, alternative option for radical Muslims, alongside the 'salafists' and Hizb al-Tahrir.[24] While some of those who got involved in jihadist plots have had histories of involvement with specific radical groups like Al Muhajiroun, this is by no means uniformly the case. On the other hand, even for people who have reached the point of being active members of a group like Al Muhajiroun it still remains very unlikely that they will actually go on to be involved in an act of terrorism. Even so, Wiktorowicz's conceptualization offers a significantly more insight into individual processes of radicalisation than do those we have just surveyed. His model of involvement in Al Muhajiroun is a perfect example of bounded rationality at work, whereby information asymmetries and human cognitive biases (like the sunk costs fallacy) work in conjunction with issue framing to produce collective action.

Given the looser nature of global jihadism, and the necessarily more spontaneous and informal forms of mobilization it employs, theories of collective action framing as originally put forward by Benford and Snow have come to be seen as particularly useful in understanding how influences such as radical propaganda might serve to move people towards violent action.[25] Even where framing theory is not explicitly drawn on, terms which recall the theory like discussions of which narratives 'resonate' are often deployed in discussing the effect of such content. However, the problem with such loose usages is that they often seem to treat framing as if it were simply another, more academically correct way to talk about the commonsense idea that radical ideas make people 


\section{Journal of Terrorism Research}

do radical things. In fact, as understood within social movement theory, framing is a rather subtler process. It works not by giving people a new set of beliefs as such (while not all theorists of collective action framing agree on the precise difference between framing and ideology, all seem to agree that they are not the same thing),[26] but rather by causing people, within more or less preexisting belief structures to see a certain issue in a different way. For instance, framing the Bosnian civil war as an attack on Muslims by Christians, rather than an attack on one former Yugoslav ethnic group by another.

The tendency to see jihadist radicalisation as a rather passive process resulting from the consumption of radical narratives has achieved perhaps its most rigorous formulation in the 'rapid evidence assessment' of Al Qaeda influenced radicalisation conducted on behalf of the UK Home Office by the criminologists Per-Olof Wikström and Noémie Bouhana.[27] In this review, the authors propose to understand the phenomenon through a theory called situational action theory. Situational action theory represents almost the perfect opposite end of the spectrum from neoclassical ideas of rational choice in so far as it conceives of human behaviour as primarily rule guided, with rational maximization of utility sidelined almost completely. Accordingly, Bouhana and Wikström interpret jihadist radicalisation almost as a public health issue, whereby individuals with certain forms of vulnerability are more susceptible than others to falling prey to a narrative which causes them to perceive terrorist acts as viable action possibilities.

This approach, it seems to me, suffers from an opposite problem to that faced by rational choice theories in seeking to explain radicalisation into jihadist terrorism. Whereas theories founded on a more or less classical conception of rational choice struggle to explain why people would carry out acts of terrorism at all, theories based on the idea that people act according to linguistically scripted rules seem to me to suffer from an opposite problem: they fail to accommodate the possibility of conflicts of interest between jihadist radicals and the Al Qaeda at the strategic level.

What I would propose is that we can arrive at a more nuanced alternative model more capable of accommodating individual agency by looking back at the actual implications of framing theory. 'Framing' is, albeit in a slightly different sense to that used in the social movement literature, an essential concept to the idea of bounded rationality as set out originally by Amos Tversky and Daniel Kahneman.[28] This is, in their work, because humans happen to have cognitive biases which mean that they consistently prefer one logically identical situation over another depending on how the two situations are presented to them (the glass half full is better than the glass half empty, saving the lives of $25 \%$ of a group is better than letting $75 \%$ of a group die). However, it may be suggested that it is also for a more universal and metaphysical reason, namely, that reason needs something to be reasonable about. A person who has read and taken to heart the book of Ecclesiastes may, for example, despair of life and consider everything to be mere vanity. If such a person then loses the will to eat, drink or look after his personal hygiene he is not being irrational. Rather, he is rationally acting (or not acting) within a different set of framing assumptions from someone who subscribes to the idea that life is worth living, and human company worth keeping. As, for example, the anthropologist George Marcus notes in this exploration of the idea of affective citizenship, emotion is not so much an obstacle to the action of reason, as a requirement for it to operate.[29]

By inviting a person to frame an issue differently, then, what one is doing is not so much demanding of her that she a in a particular way, but rather creating for her a different set of subjectively perceived goods to rationally pursue. To provide an example of what this might mean in practice, consider concepts such as glory or honour. These notions are wholly socially constructed. But to those who accept the ideological system which grants them meaning they are real enough. 


\section{Journal of Terrorism Research}

Moreover, once they are brought into being, they acquire a reality which may go beyond the interests of those behind the ideological system which brings them into being. For example, the commander of an army might find it useful to inculcate a notion of glory in his soldiers as a way of getting them to do things in the absence of more concrete incentives. However, once established, there might well be situations in which the pursuit of glory would lead soldiers to act in ways that were counterproductive to the strategic interests of the army.

Indeed, if we look at the discourses which are used by Al Qaeda's central leadership, as well as other entrepreneurs of global jihad, in an attempt to 'incite' Muslims to take part in acts of so-called 'individual terrorism', there does indeed appear to be a clear recognition that the people they are addressing are rational actors who make active choices between the costs and benefits associated with pursuing subjectively constructed goods. Thus we find that discourses seeking to mobilise people to individual jihad pursue two main rhetorical strategies. First, they try to emphasise the benefits and downplay the costs of involvement in acts of individual terrorism, as well as to emphasise the merits of carrying out operations in the West over alternative courses of action, such as travelling to fight abroad. Second, they try to encourage less costly activities of roughly escalating intensity, such as participating in boycotts, supporting prisoners, participating in propaganda work, fundraising and physical preparation.[30] It is also worth pointing out that some of these activities (e.g. supporting prisoners) can also be seen as attempts, albeit limited, to offset some of the costs of involvement in jihadist activity by promoting a wider community of support. Indeed, in certain places, these calls to arms seem to reveal an acute awareness to some of the major obstacles to engagement as, for instance, where Adam Gadahn makes the following rather unconvincing attempt to downplay the significance of being imprisoned for terrorist offences.

And I would like this note of reassurance and encouragement: if it is Allah's will that you be captured, then it's not the end of the world, and it doesn't necessarily mean that you're going to spend the rest of your life in prison. And in fact, let me tell you something: over these past few years I have seen the release of many, many Mujahideen whom I'd never even dreamed that they would regain their freedom. Yet, as I speak, now they're back home with their families or back on the frontlines fighting the enemies. So, the unbelievers' plot, and Allah plots, and Allah is the best of plotters, and he is the best of guardians and protectors, and he is the one who answers the one in need when he calls on him.[31]

What might these discourses have to tell us about the limitations to grassroots jihadist targeting observed above? Firstly, we can observe an obvious contradiction which, so it seems, jihadists are themselves aware of and find troubling. If it is indeed possible to participate in jihad by non-violent means, then were does this leave the individual obligation to participate in jihad? As Abu Mus'ab al-Suri observes, many are needed to fight, and only relatively few to carry out acts such as propaganda.[32] Moreover, Al-Suri actually seeks to discourage propagandists from getting involved in violence on the grounds that doing so represents a threat to operational security. And yet, viewed as a process of engagement, lower risk actions such as propaganda are also apparently recognised by jihadists as a necessary transitional step on the way to physical involvement. Thus those who would seem to be the candidates most likely to be committed to violent action are precisely those whom al-Suri discourages from involvement and who also, on that account, possess a useful rationale for not being so involved. Moreover, since the jihad is, in reality, not a hierarchical army capable of assigning its recruits to roles by some rational process, there is no way to say for the case of a given individual that their actions are superfluous and therefore do not amount to discharging the duty of jihad. 


\section{Journal of Terrorism Research}

Thus, rather than fulfilling their function of inciting people to action, jihadist discourses aimed at recruitment seem to contain within them the possibility of relatively stable, long term, behaviourally non-violent engagement. Moreover, another aspect of jihadist attempts at incitement would also appear to offer an explanation for why jihadists operating alone or as unsupported self-starter cells would be likely to choose more expressive and discriminate targets. This is that, in attempting to argue for the benefits of individual action to the individual, there is a tendency for jihadist discourse to emphasise religious and spiritual justifications more than the collective, strategic justifications characteristically provided by the Al Qaeda leadership's official discourse. A good example of this are the first two distinctively 'jihadi' pieces of work produced by Anwar al-'Awlaqi.[33] Indeed these texts are arguably doubly interesting in so far as they not only provide examples of a skilled and experienced ideologue trying to incite violence in an audience he knew well, but also, perhaps, some insight into the radicalisation process which he himself was going through at this point as he moved away from an explicit stance in favour of peaceful, if culturally distant coexistence between Muslim minority populations and the other inhabitants of countries they lived in towards an attitude in favour of all out war in such contexts. As such, it is telling that Al-'Awlaqi's first two texts were commentaries first on a book by the medieval 'embattled scholar' Ibn Nuhas, the title of which translates roughly as Water Holes for the Feelings of Longing for the Battlefields of the Dear Companions and the more contemporary Constants in the Practice of Jihad by the deceased former leader of Al Qaeda in the Arabian Peninsula, Yusuf al-'Uyayri. In both works the emphasis is very heavily on, as Al-'Awlaqi puts it in the latter work, jihad as 'a good in its own self'. In both, violent jihad is presented as a spiritual struggle in which victory is ultimately not of this world, but rather is achieved through the mujahid's victory over the temptations of earthly pleasures.

Formulated in this way - as a spiritual quest rather than the instrumental practice of a strategic campaign - the targeting priorities of jihadist violence would appear to look somewhat different. Most importantly, the kinds of attack which have come to be seen as paradigmatic of Al Qaeda indiscriminate mass casualty suicide bombings move from being of central importance to being permissible, but suboptimal courses of action. Consider, for example, what Abu Muhammad alMaqdisi, probably the pre-eminent example of a contemporary jihadi scholar, has to say about the permissibility of suicide operations.

I disagree with those who regard it as suicide and that the Effort should be made in using the latest technological methods like remote control bombing devices which minimise the number of victims in the ranks of the mujahidin, for this is obligatory upon them if it is attainable.

The operations should focus on military targets which distress the enemy and should manifest the radiant image of Islamic Jihad by avoiding intentional killing of children and their like

The motive behind such operations should be to establish a truly important benefit, or to repel a true blight... that cannot be repelled in any other way. executor is decreed to hellfire... however, what should be noted is that there are general, literal evidence that forbids self-killing under any circumstance, even if was not due to the abovementioned 


\section{Journal of Terrorism Research}

incentives... I directed the youth who are in charge of such operations to study the matter

legally and seriously... [34]

He goes on to insist on a set of conditions for the justifiable use of the operational method:

1. Effort should be made in using the latest technological methods like remote control bombing devices which minimise the number of victims in the ranks of the mujahidin, for this is obligatory upon them if it is attainable.

2. The operations should focus on military targets which distress the enemy and should manifest the radiant image of Islamic Jihad by avoiding intentional killing of children and their like

3. The motive behind such operations should be to establish a truly important benefit, or to repel a true blight... that cannot be repelled in any other way.

The point is that Al-Maqdisi sees suicide bombing, both in its suicidal and its indiscriminate features not as impermissible, but as very much outside normative ideal of jihadist violence. Considered from the point of view of a rational actor then, albeit one whose rationality is bounded by the jihadist frame, one who is likely to get just one attempt at fighting jihad, it is not hard to see why such an action would not necessarily be seen as optimal. By contrast, actions which are clearly meaningful and just - killing soldiers, or clearly defined 'enemies of Islam' - precisely those actions which account for most acts by genuine grassroots jihadists can readily be seen as, from an individualistic point of view, as attractive targets.

As a final thought, it is of interest to consider whether the contradictions which seem to limit the success of attempts by Al Qaeda more broadly by global jihadist ideologues to inspire individual jihad are inevitably flawed, or whether it might, after all, be possible to build a more successful and therefore threatening leaderless campaign within the jihadist framework. One interesting common feature of most jihadist discourses which seem to be aimed at inspiring individual action is a recognition that the potential range of targets and methods for violent action is extremely broad.[35] Indeed, as attempts to incite violence, jihadist discourses produced by established ideologues are often surprisingly vague on the specific sorts of violence one might attempt, providing long lists of often generic targets rather than specific, focused targets with clear explanations of why attacking them is so worthwhile. To this there is one particular and rather interesting exception which I have already mentioned - Al-'Awlaqi's 'cartoons campaign'. Here, a very specific type of target is mentioned. Indeed, Inspire Magazine actually goes further, by listing the names of specific individuals. This sort of campaign is interesting in so far as it seems to bear a close resemblance to other campaigns of leaderless resistance such as those of the Earth Liberation Front, the Animal Liberation Front and, perhaps most relevant to our purposes, campaigns of anti-Abortion extremism fronted by ideological brand names like the Army of God.[36]

While, clearly, there is not space for anything more than the briefest sketch here, comparing antiblasphemer violence by jihadists, and anti-abortion violence by militant Christians on the one hand, and the more normal targeting discourses of jihadist militancy on the other is instructive. In the former case, it can be observed that not only is the target of the proposed violence made clear from the outset but, moreover, both the ideological and instrumental purpose of the attack is clearly encoded in the act itself. When an abortion providing doctor is murdered, or an abortion clinic is attacked; or when a blaspheming cartoonist is murdered, or a blaspheming magazine office burned there is no need to provide further ideological explanation of the attacker's purpose or what he was trying to achieve. Indeed, such attacks are often recorded in databases simply as 'abortion related'. [37] The ideology of the attack is encoded in the action. Moreover within the action there is a clear 


\section{Journal of Terrorism Research}

convergence of instrumental, ethical, and group-solidarity forming rationales: killing doctors who provide abortions is a good way of making abortion less available generally; [38] it is incontrovertibly just, provided that one accepts that abortion is murder and, moreover, for this very reason, it sits at a cultural fault line: those who accept that abortion is murder and those who do not may agree on many other matters; but this is a matter on which they can, for important reasons of principle, neither agree nor agree to disagree. Again, while the case of the blaspheming cartoonist or author is plainly less clear-cut, something roughly similar might be imagined to hold. The Western Muslim who might agree with her fellow citizens on almost every other matter, might still not think that the law should permit cartoons which insult her religion. A liberal citizen of a Western country who might think of himself as generally tolerant and broad minded might nonetheless view the right to lampoon religion as sacrosanct.

What can we then learn from the story of - so far at any rate - the overall failure of Al Qaeda's attempts to instigate acts of individual jihad? Perhaps the most important observation is that the dangerousness of a form of 'violent extremism' is not necessarily proportional to the militancy of its ideology, nor that the relationship between discourse and violent action can be seen as a simple process of internalizing the explicit beliefs which the discourse teaches. Discourses also do things and invite particular forms of engagement which, in turn, may make violent action more or less plausible. Secondly, assessing the potential impacts of terrorism is about more than body count or dollar count. Acts of terrorism - where they are effective - are themselves part of the cultural discourse of violent extremism. They are acts in and on culture, and it is where they threaten to strike areas of cultural 'criticality' that they are of most real concern.

About the author: Dr Gilbert Ramsay recently completed his doctorate at the University of St Andrews, which examines the consumption of jihadist online content from a subcultural perspective. He teaches and writes on jihadist ideology and culture, 'cyberterrorism' and 'terrorism on the Internet' and online dimensions of counterterrorism policy. Themes in his present research interests relate to the intersection of political movements with popular culture and fantasy, the politics of individual excellence and virtue, the notion of the subcultural 'ethic' and subcultural perspectives on understanding limitations to target choice and modus operandi by violent political movements.

\section{Notes:}

[1] Olivier Roy, "Al Qaeda in the West as a Youth Movement: The Power of a Narrative”, CEPS Policy Brief, No. 168, August 28, 2008

[2] Brian A. Jackson, "Groups, Networks or Movements: A Command and Control Approach to Classifying Terrorist Organisations and its Application to Al Qaeda", Studies in Conflict and Terrorism, Vol. 29, No. 3, 2006

[3] H. Keith Henson, 'Sex, Drugs, and Cults. An evolutionary psychology perspective on why and how cult memes get a drug-like hold on people, and what might be done to mitigate the effects'. The Human Nature Review, 2, 2002, 344-355

[4] Metropolitan Police commissioner Ian Blair, interviewed after the 7th July attacks in London

[5] AdamYahiya Gadahn, "You are only responsible for yourself", 3rd June, 2011, available from http://www.globalterroralert.com/ al-qaida-leaders/834-as-sahab-media-you-are-held-responsible-only-for-thyself-part-1-.html

[6] It is interesting to observe that even this protection does not just extend to Muslim religious leaders. Thus there is no apparent contradiction in the thought of, e.g., Al-Suri or Abd al-Aziz al-Muqrin, between calling for the deliberate targeting of Jewish people, but disapproval of the targeting of Rabbis or synagogues. The reasoning seems to be that Islam is bound to tolerate Judaism as $a$ religion, but that Muslims as a nation are at war with Jews as a nation. 


\section{The Centre for the Study of Terrorism and Political Violence Journal of Terrorism Research}

[7] Usama bin Ladin, "9/11 Message to the American People”, 13 September 2009

[8] Alex Schmid and Albert Jongman, Political Terrorism: A New Guide to Actors, Authors, Concepts, Theories, Databases and Literature, Amsterdam: Transaction, 2005, p. 3

[9] Ayman al-Zawhairi, Knights Under the Prophet's Banner, (translated and partially condensed by Al Sharq al-Awsat) p. 62

[10] Usama bin Ladin, "Message to Our Muslim Brothers in Iraq", 2003. This is specifically what Bin Ladin says on the subject: 'We stress the importance of the martyrdom operations against the enemy - operations that inflicted harm on the United States and Israel that have been unprecedented in their history, thanks to Almighty God.'

[11] Mustafa Settmariam Nasar (Abu Mus'ab al-Suri), The Global Islamic Resistance Call, p. 1389

[12] Inspire Magazine, no. 3, 2010

[13] Inspire Magazine, no. 1, 2010

[14] These remarks are based on ongoing research for the Home Office funded project Cultural Constraints on Jihadist Terrorism. However, for an example of how new information has dramatically changed our understanding about the role of central facilitation in Al Qaeda attacks in Europe see Fernando Reinares, “The Madrid Bombings and Global Jihadism”, Survival, vol. 52, no. 2, 2010 pp. 83-104

[15] The Global Islamic Resistance Call

[16] "You are only held responsible for yourself"

[17] Dipak K. Gupta, “Towards and Integrated Framework for Analyzing Terrorism: Individual Motivations to Group Dynamics”, Democracy and Security, Vol. 1 No. 1, 2005, pp. 5-31

[18] For a useful review of theories of bounded rationality relevant to collective action see Karl Dieter Opp, Theories of Political Protest and Social Movements: A Multidisciplinary Introduction, Critique and Synthesis, London: Routledge, 2010, p. 3-8

[19] Marc Sageman, Leaderless Jihad: Terror Networks in the 21st Century, Philadelphia: University of Pennsylvania Press, 2008

[20] Eli Berman, Radical, Religious and Violent, Cambridge, Massachusetts: MIT Press, 2009

[21] Rodney Stark and William Sims Bainbridge, A Theory of Religion, New York, P. Lang, 1987

[22] Laurence Iannacone, "Why Strict Churches are Strong”, American Journal of Sociology, Vol. 99, No. 5, March 1994, pp. 11801211

[23] Quintan Wiktorowicz, Radical Islam Rising: Muslim Extremism in the West, Lanham, Rowmand and Littlefield, 2005

[24] ibid. p. 101

[25] See Robert Benford, "Framing Processes and Social Movements: An Overview and Assessment", Annual Review of Sociology, Vol. 26, August, 2010, pp. 611-639

[26] See e.g. Pamela E. Oliver and Hank Johnston, "What a Good Idea! Ideologies and Frames in Social Movement Research", Mobilization: An International Quarterly, Vol. 5, No. 1, Spring 2000, pp. 37-54.

[27] Per Olof Wikström and Noémie Bouhana, “Al Qa‘ida Influenced Radicalisation: A Rapid Evidence Assessment Guided by Situational Action Theory”, Home Office, 2011

[28] Amos Tversky and Daniel Kahneman, "The Framing of decisions and the psychology of choice" Science Vol. 211, 1981, pp. $453-458$.

[29] George Marcus, The Sentimental Citizen: Emotion in Democratic Politics, Philadelphia: Pennsylvania State University Press, 2002

[30] The obvious examples of this would be texts such as Isa bin Awshan's 39 Ways to Serve Jihad and the Mujahidin and Anwar al-'Awlaqi's adaptation of this, 44 Ways to Serve Jihad 


\section{Journal of Terrorism Research}

[31] You are only held responsible for yourself (translation by Flashpoint Partners, 2011)

[32] The Global Islamic Resistance Call

[33] For a chronology of al-'Awlaqi's publications and their possible relationship to his own trajectory of radicalisation, see Alexander Meleagrou Hitchens and Jacob Amis, "The Making of the Christmas Day Bomber”, Current Trends in Islamist Ideology, Vo. 10, 2010

[34] This statement comes from an interview quoted in the introduction to the Al-Tibyan translation of Al-Maqdisi's book, This is Our Aqidah, available from www.tawhed.ws. In the remainder of the quotation, he is drawing on the Arabic text of his response to an article published in the newspaper Al-Sharq Al-Awsat offering an Islamic critique of the legitimacy of suicide operations.

[35] This point is made directly, for example, in Inspire 4 and, more directly, in Al-'Awlaqi's recently released posthumous piece on targeting in Inspire 8. It is also implicit in the very broad range of targets in, for example, The Global Islamic Resistance Call or Abd al-Aziz al-Muqrin's piece for Al-Battar Military Camp magazine, 'The Targets in Cities'.

[36] According to Carol Mason the Army of God is simply a name used by certain radical anti-abortion activists as a collective cover for their violent actions . See Carol Mason, 'Who’s Afraid of Virginia Dare: Confronting Anti-Abortion Terrorism after 9/11”, website claiming to represent the entity still remains accessible at http://www.armyofgod.com/.

[37] This the case, for example in the Global Terrorism Database.http://www.start.umd.edu/gtd/

[38] For an examination of the effects of anti-abortion violence on abortion provision see Mirelle Jacobson and Heather Royer, "Aftershocks: The Impact of Clinic Violence on Abortion Services”, RAND Corporation, 7th July, 2010,Journal of Constitutional Law, Vol. 6, No. 4, 2004, pp. 796-817 